\title{
Impact of climate change on rice yield in the main rice growing areas of Peninsular Malaysia
}

\begin{abstract}
Agricultural sector is one of the sensitive areas that would be affected by the changes in key climatic elements. This study assesses the possible impact of climate change on the Malaysian rice production. The study employed DSSAT Crop Simulation Model to predict the rice yields in the eight granary areas of Peninsular Malaysia until 2030, based on projected weather data and current management practices. Increase in temperature and variations in rainfall pattern over the growing period were found to affect the rice yield. The results indicated that rice yield, during 2013 to 2030, compared to the base values are expected to decrease by12.2, 13.6, 8.7, 8.4, 15.2, $16.8,11.4$ and $18.6 \%$ for the main season and 45.5, 19.4, 33.9, 36.3, 34.5, 47.8, 21.8 and 7.5\% for the off season for MADA, KADA, Kerian, BLS, Pulau Pinang, Seberang Perak, Ketara and Kemasin, respectively. These results showed that rice yield would be more negatively affected by the climate change during off season rather than main season.
\end{abstract}

Keyword: Climate change; Rice; Eight granary areas; Malaysia 